\title{
HIDDEN CURRICULUM DAN PROBLEM LINGKUNGAN PENDIDIKAN ISLAM
}

\author{
WAWAN SETIAWAN
}

\begin{abstract}
Islam education environment is faced with quite serious problem, and the solutions must be sought immediately. The education that given by family environment, madrasah environment, and community environment has not shown significant results. At least it can be seen that a lot of madrasah's students who still do misconductthat is not accordance with the value of Islam it self. In other hand, they good in academic, but in other condition they have not been able to apply Islamic value in their life. There are still madrasah student who steal, hurt teacher even their parent and other immoral acts. Hidden curriculum so far has not placed it should be, it's mean the existence of hidden curriculum has not been optimally implemented in Islamic education environment. Islamic educational institution are stiil focused on the ideal curriculum and actual curriculum. Whereas through of hidden curriculum there found moral values, religious and culture that can be instilled the student.
\end{abstract}

Keywords: Hidden curriculum, problems, Islamic education environments

\section{Pendahuluan}

Pendidikan merupakan unsur yang memiliki kekuatan luar biasa dalam membangun kemajuan bangsa, sebagai salah satu penentu nasib manusia, baik sebagai individu, masyarakat maupun bangsa. Berdasarkan pemikiran tersebut, perkembangan gagasan tentang pendidikan yang menjadi dasar terbentuknya pendidikan berkualitas perlu terus dikembangkan agar pendidikan dapat berfungsi secara maksimal dalam membentuk manusia yang berkualitas guna memenuhi harapan keluarga, masyarakat dan bangsa.

Banyak pendapat mengatakan bahwa pendidikan di Indonesia tidak berhasil karena tidak mampu menghasilkan lulusan siap pakai. Namun sebetulnya selain permasalahan tersebut ada masalah yang lebih besar yaitu lulusan pendidikan kita masih sanggup berbohong, merampas hak orang lain, korupsi, ingin benar sendiri, tidak menghargai pendapat orang lain, tidak mampu hidup berdampingan dengan orang lain. Padahal pendidikan diselenggarakan dengan tujuan untuk lebih memanusiakan manusia, agar derajat manusia menjadi lebih tinggi. 
Tafsir (2014:133) berpandangan bahwa manusia terdiri dari tiga unsur, yaitu jasmani, rohani dan rasa. Unsur jasmani bila dididik dengan benar akan menghasilkan jasmani yang sehat dan kuat, unsur akal bila dididik dengan baik akan menghasilkan akal yang memiliki kecerdasan yang tinggi, unsur rasa atau hati yang dididik dengan benar akan menghasilkan nurani yang sehat dan tajam. Perkembangan harmonis ketiga unsur ini akan menghasilkan manusia yang utuh (kaffah). Dalam kajian lebih lanjut ternyata ditemukan bahwa antara ketiga unsur tersebut ternyata unsur hati atau rasa itulah yang merupakan unsur terpenting pada manusia. Ini diketahui diantaranya dalam salah satu sabda Rasulullah SAW yang mengatakan bahwa: "Di dalam diri manusia itu ada segumpal daging, bila daging itu baik maka baiklah keseluruhan manusia itu dan bila daging itu jelek maka jeleklah keseluruhan manusia itu, daging itu adalah hati".

Jika kita lihat pendidikan kita terlalu mengutamakan pendidikan aspek jasmani dan akal, sedangkan aspek hati kurang mendapatkan perhatian serius, maka janganlah kaget jika kita memiliki lulusan yang sehat serta kuat jasmaninya, cerdas serta pandai akalnya, tetapi ia belum mampu menampilkan dirinya sebagai orang yang baik. Oleh sebab itulah banyak diantara lulusan sekolah kita, walaupun nilai akdemiknya bagus tapi masih melakukan perbuatan tercela, tidak konstruktif dalam masyarakat.

Pendidikan segi jasmani sudah difasilitasi oleh mata pelajaran Pendidikan Jasmani Olahraga dan Kesehatan (PJOK), hasinya adalah lulusan yang sehat serta kuat. Untuk segi akal disediakan mata pelajaran seperti matematika, fisika, biologi dan lain-lain, hasilnya melahirkan siswa yang pintar secara logika, memiliki nilai akademik yang bagus namun belum menyadari bahwa alam semesta beserta hukum alamnya adalah ciptaan tuhan. Untuk pendidikan rasa atau hati diadakan mata pelajaran agama. Namun sangat disayangkan masih banyak diantara guru di madrasah/sekolah yang mengajarkan agama agar siswa memiliki pengetahuan tentang agama. Hasilnya mereka mengetahui tentang ibadah, ahlak, tahu bahwa berbohong itu salah, mencuri dilarang, shalat itu wajib tapi mereka tidak dapat mengaplikasikan pengetahuan agamanya itu kedalam perilaku sehari-hari. Jika pendidikan kita terus menerus seperti itu maka hanya akan menghasilkan lulusan yang sehat kuat, cerdas pandai akalnya tetapi ruhaninya kering.

Secara sederhana, hasil suatu pendidikan sangat ditentukan oleh bagaimana sebuah lembaga pendidikan mewujudkan tiga aspek penting pendidikan, yaitu : bagaimana menyiapkan rencana pendidikan, bagaimana melaksanakan rencana pendidikan yang telah dibuat, dan bagaimana menyiapkan lingkungan yang mendukung rencana dan penerapan rencana tersebut. Ketiga aspek pendidikan tersebut dalam disiplin ilmu kurikulum seringkali disebut dengan tiga bentuk kurikulum. Bentuk rencana pendidikan disebut dengan kurikulum ideal atau kurikulum tertulis, bentuk pelaksanaan kurikulum disebut dengan kurikulum aktual, dan bentuk lingkungan yang 
mendukung kurikulum ideal dan kurikulum aktual disebut dengan kurikulum tersembunyi (Nurhalim:2014:3).

Hidden curriculum adalah segala hal yang terjadi dalam proses pelaksanaan kurikulum ideal menuju kurikulum aktual. Semua hal tersebut berupa pengaruh yang berasal dari semua pihak yang terkait dengan proses belajar mengajar di sebuah lembaga pendidikan. Bisa pengaruh dari orang tua, tokoh masyarakat, guru atau tenaga pendidik, kepala sekolah selaku pimpinan, tenaga kependidikan, atau bahkan dari peserta didik itu sendiri. Kedisiplinan dan konsistensi guru misalnya dengan datang tidak terlambat di kelas, merupakan bagian dari kurikulum tersembunyi yang akan membentuk karakter peserta didik.

Sejarah mencatat bahwa semenjak diberlakukannya kurikulum pendidikan di Indonesia tahun 1947, kurikulum telah silih berganti dengan berbagai wujud perubahannya. Tetapi satu hal yang selalu terulang dari berbagai penerapan kurikulum yang telah dihasilkan dari pemikiran dan upaya yang sungguh-sungguh dari para ahli dan pengembang kurikulum tersebut adalah bahwa hasil penerapan kurikulum selalu saja dianggap kurang memuaskan, dianggap tidak bisa menjawab persoalan yang ada, dan belum menghasilkan output sebagaimana apa yang diharapkan dalam cita-cita pendidikan nasional (Nurhalim:2014:1).

Melalui penerapan hidden curriculum, lingkungan pendidikan akan memberikan kontribusi yang positif terhadap proses belajar mengajar. Baik lingkungan keluarga, lingkungan sekolah maupun lingkungan masyarakat, jika dibentuk menjadi lingkungan yang kondusif untuk mendukung pendidikan anak, maka akan menghasilkan anak didik yang mempunyai kecerdasan majemuk, yakni cerdas intelektualnya, cerdas emosinya dan juga cerdas spiritualnya.

Sudah saatnya lembaga pendidikan kita, khususnya lembaga pendidikan Islam, memberikan perhatian yang khusus kepada penerapan kurikulum tersembunyi (hidden curriculum). Masalah moral, ahlak dan nilai tidak hanya cukup dengan penyampaian secara lisan melalui ceramahceramah kepada anak didik saja, melainkan harus diberikan penguatan dengan contoh nyata melalui pemberian contoh/keteladanan dan pembiasaan. Itu semua dapat ditanamkan dengan menerapakan hidden curriculum atau kurikulum trsembunyi.

\section{Metode Kajian}

Kajian ini menggunakan metode survei pustaka, di mana penulis melakukan kajian terhadap sejumlah literatur yang relevan, yang berhubungan dengan gagasan hidden curriculum yang kemudian dihubungkan dengan problem lingkungan pendidikan Islam. 


\section{Hasil Kajian dan Pembahasan}

Kurikulum pada intinya merupakan perencanaan tentang pencapaian yang harus dicapai oleh peserta didik. Dengan berbagai mata pelajaran yang diajarkan menjadikan peserta didik paham dengan ilmu pengetahuan. Ilmu pengetahuan ini termasuk aspek kognitif. Sedangkan aspek afektif dan psikomotorik yang akan terbentuk melalui pembelajaran masih sangat kurang diperhatikan oleh lembaga pendidikan. Aspek inilah kemudian yang dikatakan dengan kurikulum tersembunyi atau hidden curriculum. Kurikulum tersembunyi tersebut sebenarnya sangat berpengaruh pada pendidikan peserta didik.

Terdapat dua hal yang dapat dipahami dalam pengertian kurikulum, yaitu kurikulum pada aspek program atau rencana, yang pada hakikatnya adalah kurikulum ideal (ideal curriculm) dan kurikulum pada aspek pengalaman belajar siswa, yang pada hakekatnya adalah kurikulum aktual (actual curriculum). Kurikulum ideal merupakan kurikulum yang menggambarkan suatu cita-cita dalam bidang pendidikan yang diharapkan dapat dilaksanakan dan berfungsi sebagai acuan atau pedoman dalam proses pendidikan. Adapun kurikulum aktual adalah kurikulum yang disajikan di hadapan kelas yang merupakan penjabaran dari kurikulum ideal. Dalam kurikulum aktual inilah terdapat hidden curriculum, karena hidden curriculum ini dilaksanakan dan dialami oleh peserta didik di ruang kelas dalam proses kegiatan pembelajaran maupun di luar kelas.

Arifin (2011:7) menjelaskan bahwa kurikulum tersembunyi atau hidden curriculum itu adalah segala sesuatu yang mempengaruhi peserta didik yang berkaitan dengan perilaku positif ketika sedang mempelajari sesuatu. Pengaruh itu bisa berasal dari guru, sesame peserta didik, kepala sekolah, lingkungan sekolah dan suasana belajar di kelas.

Hidden curriculum secara teori sangat rasional dalam mempengaruhi siswa, baik menyangkut lingkungan sekolah, suasana kelas, pola interaksi guru dengan siswa di dalam kelas, bahkan pada kebijakan serta manajemen pengelolaan sekolah secara lebih luas dan perilaku dari semua komponen sekolah dalam hubungan interaksi vertikal dan horizontal.

Melihat berbagai pengertian tersebut penulis berkesimpulan bahwa yang dinamakan hidden curriculum merupakan kurikulum yang tidak terlihat, namun berperan dalam pencapaian tujuan pendidikan. Kurikulum tersembunyi merupakan sesuatu yang menjadi misi khusus yang hanya diketahui oleh seorang guru ataupun pengelola pendidikan. Hidden curriculum bisa diartikan sebagai segala sesuatu yang terjadi secara tiba-tiba tanpa perencanaan terlebih dahulu yang dapat dimanfaatkan oleh guru dalam rangka mencapai tujuan pembelajaran.

Hidden curriculum atau kurikulum tersembunyi mempunyai peran yang penting dalam pendidikan nilai/pembentukan karakter siswa, namun seringkali keberadaannya kurang menjadi perhatian. Oleh sebab itu lembaga 
pendidikan harus mampu mengkombinasikan antara kurikulum ideal, aktual dan tersembunyi dengan baik. Dengan penerapan kurikulum tersembunyi akan membawa setiap kegiatan pembelajaran lebih kondusif, karena dengan hidden kurikulum akan menjadikan guru senantiasa mawas diri, dan dapat dijadikan tauladan bagi para peserta didik (Zamroni, 2007:119).

Hidden curriculum memiliki beberapa fungsi. Pertama, hidden curriculum dapat menghasilkan pemahaman yang mendalam tentang kepribadian, norma, nilai, keyakinan yang tidak dijelaskan secara menyeluruh dalam kurikulum formal. Kedua, hidden curriculum berfungsi untuk memberikan kemampuan dan keterampilan yang sangat bermanfaat bagi peserta didik sebagai bekal dalam fase kehidupannya di kemudian hari. Dengan kata lain, hidden curriculum dapat menyiapkan peserta didik agar siap terjun di lingkungan masyarakat.Ketiga, hidden curriculum dapat menciptakan masyarakat yang lebih demokratis.

Fungsi keempat, hidden curriculum juga dapat berfungsi sebagai alat kontrol sosial yang efektif terhadap perilaku murid maupun perilaku guru. Guru memberikan contoh, teladan, dan pengalaman yang ditransmisikan kepada peserta didik. Mereka kemudian mendiskusikan dan menegosiasikan penjelasan tersebut. Kelima, hidden curriculum dapat meningkatkan motivasi peserta didik yang selanjutnya dapat melejitkan prestasinya dalam belajar.

Hidden curriculum terbentuk dari tiga $\mathrm{R}$ yang sangat penting untuk dikembangkan, yaitu: pertama Rules atau aturan, sekolah harus menciptakan berbagai aturan untuk menciptakan situasi dan kondisi sekolah yang kondusif untuk belajar. Kedua Regulations atau kebijakan, sekolah harus membuat kebijakan yang mendukung terhadap tercapainya tujuan pembelajaran di sekolah tersebut. Kebijakan tersebut tidak hanya bersangkutan terhadap siswa tetapi perlu dibuat kebijakan untuk semua komponen sekolah, tentunya dengan formulasi yang berbeda. Ketiga Routines atau kontinyu, sekolah harus menerapkan segala kebijakan dan aturan secara terus menerus dan adaptif, tujuannya agar kebijakan tersebut dapat diterima dengan baik dan terus dapat dilaksanakan.

Lingkungan adalah seluruh kondisi dan alam sekitar yang mempengaruhi tingkah laku, pertumbuhan, perkembangan hidup manusia (Suhada, 2017). Sedangkan pendidikan Islam merupakan segala usaha untuk memelihara dan mengembangkan fitrah kemanusiaan, serta sumber daya manusia menuju terbentuknya manusia yang seluruhnya sesuai dengan syariat Islam. Pengertian pendidikan tersebut menekankan kepada perubahan tingkah laku, dari yang buruk kepada yang baik, melalui proses pengajaran. Terjadinya perubahan tingkah laku tersebut bukan saja meliputi kesalehan individu, tetapi juga kesalehan sosial. Kesalehan ini harus terwujud secara nyata dalam kehidupan manusia. Adapun lingkungan pendidikan Islam adalah suatu lingkungan yang di dalamnya terdapat ciri-ciri keislaman yang memungkinkan terselenggaranya pendidikan Islam dengan baik. 
Lingkungan mempunyai peran yang sangat penting bagi keberhasilan pendidikan Islam. Karena perkembangan jiwa anak itu sangat dipengaruhi oleh keadaan lingkungannya. Lingkungan bisa memberikan pengaruh yang positif dan pengaruh yang negatif terhadap pertumbuhan dan perkembangan jiwa anak. Positif apabila memberikan dorongan terhadap keberhasilan proses pendidikan itu. Dikatakan negatif apabila lingkungan justru menjadi penghambat keberhasilan pendidikan.

Pada periode awal umat Islam mengenal adanya lembaga pendidikan berupa kutab yang mana di tempat ini diajarkan membaca dan menulis huruf Al-Qur'an lalu diajarkan pula ilmu Al-qur'an dan ilmu-ilmu agama lainnya. Begitu di awal dakwah Rosululloh SAW ia menggunakan rumah Arqom sebagai institusi pendidikan bagi sahabat awal (Suhada:2017). Selain itu lembaga pendidikan yang digunakan oleh Rosululloh SAW dan para sahabat adalah rumah, masjid dan madrasah. Pada perkembangan sekarang institusi pendidikan tersebut secara garis besar disederhanakan menjadi tiga macam, yaitu : Keluarga, Sekolah/madrasah dan masyarakat.

a. Lingkungan keluarga

Keluarga merupakan lingkungan pendidikan pertama tempat anak mendapatkan pendidikan. Di keluarga inilah dasar-dasar kepribadian peserta didik diterapkan pada usia yang masih muda, karena pada usia ini anak lebih peka terhadap pengaruh dari orang-orang terdekatnya. Dalam Undangundang Nomor 20 tahun 2003 tentang sisdiknas bahwa keluarga merupakan bagian dari lembaga pendidikan informal yang juga disebut sebagai satuan pendidikan luar sekolah.

Pendidikan terhadap anak-anak dalam keluarga merupakan permasalahan utama yang dibicarakan oleh Islam, bahkan sangat penting bagi masa depan umat Islam. Mereka adalah anak-anak yang harus dididik dengan sungguh-sungguh dan cermat. Mendidiknya untuk selalu konsekuen, menjelaskan yang halal dan yang haram, menggambarkan batasan-batasan kehidupan dalam Islam dan menerapkan etika pergaulan dengan ahlakul karimah.

Dalam keluarga yang bertindak sebagai guru adalah orang tua, kerabat, dan sanak family lainnya. Orang tua selain bertindak sebagai pendidik juga bertindak sebagai penanggung jawab. Oleh karena itu orang tua dituntut untuk menjadi suri tauladan bagi anak-anaknya, baik yang berkenaan dengan ibadah, ahlak dan sebagainya. Dengan demikian kepribadian anak yang islami akan terbentuk sejak dini sehingga akan menjadi modal awal dan akan menentukan dalam proses pendidikan selanjutnya.

b. Lingkungan Sekolah/Madrasah

Sekolah atau madrasah merupakan lembaga pendidikan formal juga menentukan dalam membentuk kepribadian anak didik yang islami. Sekolah bisa disebut sebagai lembaga pendidikan kedua yang berperan dalam mendidik anak setelah keluarga. Lingkungan madrasah merupakan 
lingkungan tempat peserta didik mendapatkan nilai-nilai akademik termasuk bersosialisasi dengan guru dan teman sekolah.

Di Indonesia lembaga pendidikan yang selalu diidentikan dengan lembaga pendidikan islam diantaranya adalah pesantren, Raudhatul Athfal (RA), Madrasah Ibtidaiyah (MI), Madrasah Tsanawiyah (MTs) dan Madrasah Aliyah (MA), termasuk juga perguruan tinggi islam seperti Universitas Islam Negeri (UIN), Sekolah Tinggi Agama Islam (STAI) dan lain-lain.

c. Lingkungan masyarakat

Kata masyarakat selalu dideskripsikan sebagai kumpulan individuindividu manusia yang memiliki kesamaan, baik dalam karakteristik maupun tujuan. Lingkungan masyarakat merupakan lingkungan/lembaga pendidikan setelah keluarga dan sekolah. Jenis pendidikan yang diterima peserta didik dalam masyarakat banyak sekali, meliputi segala bidang baik pembentukan kebiasaan, pembentukan pengetahuan, sikap, minat dan bakat maupun pembentukan karakter/ahlak dan nilai agama.

Pendidikan dalam masyarakat bisa dikatakan merupakan pendidikan secara tidak langsung, pendidikan yang dilaksanakan dengan tidak sadar oleh masyarakat. Di lingkungan masyarakat terdapat lembaga pendidikan non formal yang berpengaruh terhadap perkembangan diri anak, misalnya seperti masjid yang memegang peranan penting dalam penyelenggaraan pendidikan islam. Pengaruh masjid terhadap perkembangan peserta didik adalah bergantung dengan tinggi rendahnya kualitas maupun kuantitas aktivitas masjid di lingkungan tempat tinggalnya. Oleh karena itu menjadi kewajiban umat Islamlah untuk senantiasa berusaha memakmurkannya dengan kegiatan-kegiatan yang positif. Selain masjid ada juga kegiatan remaja/karang taruna, dalam kegiatan remaja/karang taruna ini mereka mendapatkan kesempatan dan memperoleh pengalaman-pengalaman yang meningkatkan kematangan pribadi mereka.dengan pengalaman-pengalaman tersebut mereka menemukan jati diri mereka, menemukan bakat dan potensi mereka, serta mengetahui cara bergaul yang baik.

Pendidikan dewasa ini dihadapkan pada problem parsialisasi atau fragmentasi. Parsialisasi tersebut terjadi dalam tiga hal : hakekat manusia (peserta didik dan tujuan pendidikan), kurikulum dan ilmu pengetahuan. Parsialisasi pertama memandang bahwa akal merupakan "raja" dalam struktur kepribadian anak. Sebagai akibat cara pandang seperti itu proses pendidikan mengalami pendangkalan makna menjadi proses pengajaran dan proses pengajaran mengalami pendangkalan makna berikutnya sebagai penjejalan ilmu pengetahuan ke dalam otak anak didik (Tobroni, 2008:123).

Akibat cara pandang dan perlakuan yang parsial dan tidak adil terhadap anak didik ini banyak pengamat pendidikan yang mengatakan bahwa pendidikan di Indonesia mengalami kegagalan. Setiap pergantian semester orang tua dipaksa membeli setumpuk buku baru, tetapi penghayatan terhadap isi buku itu kosong, penghayatan dan pengamalannya rendah, 
ahlaknya kurang terpuji, kepada orang tua kurang menghormati dan seterusnya.

Ketika mendengar kata "sekolah", maka asosiasi kita langsung terarah pada istilah-istilah seperti ijazah, lulus, tidak lulus, naik kelas, ranking dan lain-lain. Sadar atau tidak cara pandang seperti ini mempengaruhi cara pandang masyarakat terhadap sekolah. Masayarakat memandang sekolah hanya tempat untuk mempelajari sejumlah mata pelajaran yang terdapat dalam rapor.

Parsialisasi yang kedua ialah bagaimana cara pandang terhadap kurikulum. Madrasah jika dilihat lebih mengutamakan kurikulum formal (formal curriculum) yaitu kurikulum yang ada sebagaimana dalam silabi dan buku paket. Guru sudah merasa selesai tugasnya apabila telah mengajarkan atau menyampaikan isi buku itu kepada anak didiknya. Sedangkan kurikulum tersembunyinya (hidden curriculum) kurang diperhatikan, seperti keteladanan, kedisiplinan, pembentukan iklim pendidikan (education climate) yang lebih berpengaruh dalam pembentukan karakter anak didik. Akibatnya interaksi guru-murid lebih dominan sebagai bentuk interaksi transaksional daripada interaksi edukatif.

Ketiga parsialisasi juga terjadi dalam memandang ilmu pengetahuan. Ilmu pengetahuan dikotak-kotak antara satu dengan lainnya seakan terpisah dan tidak memiliki keterkaitan atau dengan kata lain terjadi dikotomi ilmu pengetahuan.

Parsialisasi terhadap anak didik, kurikulum dan ilmu pengetahuan tersebut tentu membawa persoalan bagi proses pendidikan maupun maksimalisasi pencapaian hasilnya. Karena itu perlu adanya reintegrasi, dan reintegrasi itu tidak perlu dilakukan dengan membongkar paradigma ilmu pengetahuan melainkan melalui spiritualisasi human beingnya baik guru maupun peserta didiknya.

Isi pendidikan di madrasah secara umum masih lebih mengutamakan penguasaan materi-materi keagamaan yang bersifat tekstual dan kurang aplikatif ketimbang materi-materi keagamaan yang kontekstual. Struktur kurikulum yang dikembangkan di madrasah juga sangat padat, sehingga terkesan kurang spesifik. Akibatnya banyak diantara lulusan madrasah yang kualitas keilmuannya masih diragukan. Penguasaan ilmu keislaman belum dapat memenuhi kebutuhan minimal masyarakat, penguasaan terhadap teknologi informasi juga dipertanyakan. Oleh sebab itu, madrasah sebagai lembaga pendidikan berciri khas islam dituntut untuk memperjelas identitas dirinya dengan melakukan berbagai perbaikan.

Hidden curriculum dan lingkungan pendidikan Islam

Sebagaimana diuraikan sebelumnya, bahwa problem besar yang dihadapi oleh lingkungan pendidikan Islam adalah terjadinya krisis ahlak atau moral yang terjadi pada peserta didik. Lembaga pendidikan baru melahirkan 
peserta didik yang cerdas secara intelektual, memiliki nilai akdemik yang tinggi namun kering dari nilai-nilai ruhani. Oleh sebab itu lembaga pendidikan perlu mengevaluasi diri, membenahi apa yang salah atau kurang pada lembaganya.

Supaya lulusan lembaga pendidikan menghasilkan sumber daya manusia yang sesuai dengan harapan, maka harus dibuat sebuah sistem pendidikan yang terpadu. Artinya, agar proses pendidikan tidak hanya terkonsentrasi pada satu unsur saja. Sistem pendidikan seharusnya memadukan atau menselaraskan seluruh unsur pembentuk sistem pendidikan yang unggul. Paling tidak ada 3 hal yang harus menjadi perhatian, yaitu : Pertama, sinergi antara lembaga/lingkungan pendidikan baik keluarga, madrasah, dan masyarakat. Pendidikan yang integral harus melibatkan tiga unsur di atas. Saat ini juka kita cermati ketiga unsur tersebut belum sepenuhnya berjalan secara sinergis, di samping juga setiap unsur tersebut juga belum berfungsi secara benar. Buruknya pendidikan anak di rumah akan memberikan beban yang berat kepada madrasah dan menambah keruwetan persoalan di tengah-tengah masyarakat seperti terjadinya tawuran pelajar, pergaulan bebas, napza, dan sebagainya. Di saat yang sama, situasi masyarakat yang buruk jelas akan membuat nilai-nilai yang mungkin sudah berhasil ditanamkan di tengah keluarga dan sekolah/kampus menjadi kurang optimum. Apalagi jika pendidikan yang diterima di madrasah juga kurang bagus, maka lengkaplah kehancuran dari tiga pilar pendidikan tersebut.

Kedua, perlu adanya kurikulum yang terstruktur dan terprogram dimulai dari tingkat TK/RA hingga ke tingkat Perguruan Tinggi Islam. Kurikulum demikian dapat menjadi solusi alternatif untuk ketersambungan pendidikan setiap peserta didik pada setiap jenjangnya. Pada pendidikan tingkat dasar seperti ini atau menjelang usia baligh, penyusunan struktur kurikulum sedapat mungkin bersifat mendasar, umum, terpadu, dan merata bagi semua anak didik yang mengikutinya.

Pada jenjang Perguruan Tinggi (PT), kebudayaan asing dapat disampaikan dan kenalkan secara utuh. Ideologi seperti sosialismekomunisme atau kapitalisme-sekularisme, misalnya, dapat diperkenalkan kepada kaum Muslim setelah mereka memahami Islam secara utuh. Pelajaran ideologi selain Islam dan ideologi lainnya diberikan bukan bertujuan untuk dilaksanakan, melainkan hanya sebatas dijelaskan dan dipahami kekurangannya serta ketidaksesuaiannya dengan fitrah manusia.

Selain itu juga lembaga/lingkungan pendidikan harus dapat mensinergikan antara kurikulum ideal yang merupakan cita-cita/tujuan pendidikan dengan kurikulum aktual yang merupakan penerapan/aplikasi dari kurikulum ideal dan kurikulum tersembunyi sebagai misi khusus penerapan nilai ahlak/karakter dari lembaga pendidikan kepada peserta didik. 
Ketiga, berorientasi pada pembentukan kepribadian Islami, tsaqofah Islamiyah dan penguasaan terhadap ilmu pengetahuan. Dalam implementasinya, ketiga hal di atas menjadi orientasi dan panduan bagi pelaksanaan pendidikan.

Setiap lembaga pendidikan seharusnya memiliki kurikulum, sesederhana apapun. Tetapi mengapa yang kita kenal hanyalah kurikulum untuk pendidikan sekolah saja, jawabannya karena kurikulum sering didefinisikan sebagai sejumlah pengetahuan yang harus dikuasai untuk memperoleh suatu ijazah (Tafsir, 2013:109).

Kurikulum dalam keluarga secara garis besarnya adalah kurikulum untuk pengembangan jasmani dan keterampilan, kurikulum untuk pengembangan akal, dan kurikulum untuk pengembangan ruhani anak. Kunci pendidikan dalam keluarga sebenarnya terletak pada pendidikan ruhani dalam arti pendidikan kalbu, lebih tegas lagi adalah pendidikan agama. Bagaimanapun sederhananya pendidikan agama diberikan di rumah, itu akan berguna bagi anak tersebut dalam memberi nilai pada teori-teori pengetahuan yang kelak akan diterimanya di sekolah. Pendidikan agama dalam keluarga adalah fondasi yang akan dilanjutkan di sekolah sebagai pengembangan.

Kurikulum di masyarakat juga sangat diperlukan. Memang sulit menentukan kurikulum di masyarakat karena cakupannya yang luas, masyarakat itu bisa di terminal, di pasar, di lapang sepak bola, di stasiun dan tempat-tempat lainnya. Namun paling tidak di majelis taklim, organisasi kepemudaan, remaja masjid, karang taruna bisa di buatkan kurikulum tersendiri. Secara umum memang kurikulum banyak yang mengartikan hanya sebatas rencana pembelajaran yang terdiri dari kumpulan mata pelajaran sesuai silabi untuk memperoleh suatu ijazah. Namun pengertian secara luas, kurikulum di masyarakat dapat dirumuskan dengan pemberian pengalaman belajar, menggali kreatifitas peserta didik, mengembangkan minat dan bakat dan kegiatan-kegiatan lainnya.

Kurikulum di lingkungan masyarakat, dalam hal ini majelis pengajian misalnya dapat dibuatkan kurikulumnya. Pembagian tema/pokok bahasan pengajian pada setiap pertemuan bisa dilakukan. Contoh minggu pertama pokok bahasannya fikih tentang tata cara wudlu, pertemuan selanjutnya tata cara shalat, syarat rukun shalat, berikutnya bisa diisi dengan tema fiqih puasa, zakat dan lainnya. Dengan program seperti ini secara tidak sadar masyarakat sudah membuat kurikulum tersendiri.

Penerapan hidden curriculum dalam rangka menanamkan nilai-nilai, khususnya nilai Islam di lingkungan keluarga, madrasah dan masyarakat bisa dilakukan melalui bentuk-bentuk kegiatan sebagai berikut:

a. Pembiasaan

Pembiasaan merupakan perbuatan yang konsisten, artinya dilakukan dengan pola yang sama. Perbuatan pada mulanya dipengaruhi oleh kerja pikiran yang didahului oleh pertimbangan akal dan perencanaan yang matang. 
Dengan kata lain lancarnya perbuatan karena perbuatan itu sering diulangulang. Hasil dari pembiasaan yang dilakukan oleh peserta didik adalah terciptanya suatu kebiasaan yang melekat bagi anak didik. Dalam proses pendidikan pembiasaan itu merupakan suatu hal yang sangat penting, karena banyak kita lihat orang berbuat dan bertingkah laku hanya karena kebiasaan semata, bukan karena pertimbangan benar dan salah.

Pembiasaan ini sebenarnya berisi pengalaman. Oleh karena itu, uraian tentang pembiasaan merupakan pengamalan dari pengetahuan yang sudah diketahui. Jadi inti dari pembiasaan adalah pengulangan. Pembiasaan di lingkungan keluarga misalnya dapat dilakukan dengan membiasakan bangun pagi hari, cuci tangan sebelum makan, bersalaman kepada orang tua ketika akan berangkat sekolah dan lain sebagainya. Di lingkungan madrasah bisa dilakukan dengan banyak cara, membiasakan shalat dhuha, membiasakan berdo'a ketika akan belajar dan setelah belajar, datang tepat waktu ke madrasah, tidak mencontek ketika ujian dan kegiatan-kegiatan lainnya. Pembiasaan di lingkungan masyarakat dilakukan dengan membiasakan solat berjamaah di masjid, mengikuti kerja bakti di lingkungan, tersenyum dan berjabat tangan dengan tetangga ketika bertemu dan lain-lain.

b. Keteladan

Keteladanan dalam proses pendidikan merupakan bagian dari sejumlah metode yang paling ampuh dan efektif untuk mempersiapkan dan membentuk anak dari segi moral, spiritual dan sosial. Orang tua, guru dan tokoh masyarakat sebagai subyek pendidikan, maka haruslah menjadi teladan bagi anak didiknya. Oleh karena itu kebiasaan-kebiasaan mereka akan menjadi sasaran tiruan bagi anak. Meniru adalah suatu faktor yang penting dalam pembentukan kebiasaan seoarang anak. Kehati-hatian orang tua, guru dan tokoh masyarakat dalam bersikap dan berucap haruslah sangat diperhatikan. Pepatah mengatakan guru kencing berdiri, murid kencing berlari.

Secra psikologis ternyata manusia memang mempunyai sifat bawaan memerlukan tokoh teladan dalam hidupnya. Peneladanan itu ada dua macam, yaitu sengaja dan tidak disengaja. Keteladanan yang tidak disengaja yaitu keteladanan dalam keilmuan, kepemimpinan, sifat keikhlasan dan lain sebagainya. Sedangkan keteladanan yang disengaja adalah seperti memberikan contoh membaca yang baik, mengerjakan shalat yang benar dan lain-lain. Keteladanan yang disengaja adalah keteladanan yang memang disertai penjelasan atau perintah untuk meneladani.

c. Pengelolaan lingkungan

Keberhasilan pembelajaran membutuhkan pengelolaan lingkungan yang baik. Pengelolaan lingkungan adalah upaya yang dilakukan oleh orang tua, guru dan tokoh masyarakat untuk mengkondisikan lingkungan dengan cara mengoptimalkan sumber belajar yang ditujukan agar proses 
pembelajaran dapat terlaksana sesuai dengan perencanaan pembelajaran dan tujuan yang ingin dicapai.

Pengelolaan lingkungan keluarga dilakukan dengan bagaimana menciptakan keluarga yang dalam bahasa agama disebut sebagai sakinah, mawaddah wa rahmah. Keluarga yang penuh cinta dan kasih saying akan melahirkan ketenangan bagi anggota keluarganya. Dengan ketenangan inilah akan tercipta suasana pendidikan yang kondusif dan akan melahirkan generasi waladun salih.

Pengelolaan lingkungan madrasah sebagai lembaga pendidikan kedua bisa dilakukan dengan pengelolaan kelas yang baik. Kelas diatur sedemikian rupa sehingga menimbulkan suasana yang kondusif dan mendukung proses pembelajaran. Misalnya dimulai dengan pembentukan struktur organisasi kelas, pengaturan posisi tempat duduk siswa, melengkapi sarana prasarana sumber belajar dan lain sebaginya.

Pengelolaan lingkungan masyarakat harus dilakukan secara bersamasama. Tokoh masyarakat, tokoh agama, para pemangku kebijakan setempat, ketua RT, ketua RW, ketua pemuda dan unsur-unsur lainnya harus bahu membahu menciptakan kondisi lingkungan yang aman, nyaman dan kondusif untuk proses pendidikan di masyarakat. Kondisi yang tertib di lingkungan masyarakat merupakan kurikulum tersembunyi yang biasanya tidak disadari oleh anggota masyarakat.

d. Tata tertib atau aturan

Tata tertib atau aturan tidak hanya membantu program sebuah lembaga pendidikan, tetapi juga untuk menunjang kesadaran dan ketaatan terhadap tanggung jawab. Karena rasa tanggung jawab inilah yang merupakan inti dari kepribadian yang sangat perlu dikembangkan dalam diri anak. Dengan demikian dapat dipahami bahwa kehidupan di keluarga, di masyarakat dan madrasah/sekolah memerlukan tata tertib, karena tata tertib merupakan salah satu alat pendidikan dan merupakan bagian dari kelancaran kegiatan belajar pembelajaran.

Aturan yang dibuat, baik di keluarga, di madrasah maupun di masyarakat harus mencakup untuk semua komponen yang terlibat di dalamnya. Peraturan yang dibuat di madrasah misalnya bukan hanya ditujukan untuk peserta didik saja tapi juga dibuat untuk guru dan karyawan bahkan penjaga kantin sekalipun.

Untuk menghasilkan pendidikan yang berkualitas, maka ketiga lembaga atau lingkungan pendidikan diatas perlu bekerja sama secara harmonis. Orang tua di tingkat keluarga harus memperhatikan pendidikan anak-anaknya, terutama dalam aspek keteladanan dan pembiasaan serta penanaman nilai-nilai. Orang tua juga harus menyadari tanggung jawabnya dalam mendidik anak-anaknya bukan hanya menjadikan anak sebagai seorang yang taat beribadah semata, tapi juga dituntut untuk mempersiapkan anaknya 
sebagai anggota masyarakat yang baik, sebab masyarakat yang baik berasal dari individu-individu yang baik.

Menyadari besarnya tanggung jawab orang tua terhadap anak-anaknya, maka orang tua sudah seharusnya selalu berkoordinasi dengan sekolah/madrasah untuk membantu kelancaran pendidikan anaknya tersebut. Pihak sekolah juga sudah selayaknya menyadari bahwa peserta didik yang ia didik merupakan amanah dari orang tua mereka sehingga bantuan dan keterlibatan orang tua sangat dibutuhkan. Kemudian madrasah juga harus bisa memberdayakan masyarakat semaksimal mungkin dalam rangka peningkatan kualitas pendidikan.

Begitu pula masyarakat pada umumnya harus menyadari pentingnya kerjasama atau sinergi yang kuat antara masyarakat sebagai lembaga pendidikan dengan keluarga dan sekolah sebagai lembaga pendidikan yang lain sehingga terjadi keterpaduan. Keterpaduan inilah yang diharapkan dapat mewujudkan tujuan pendidikan yang diinginkan.

\section{Kesimpulan}

Hidden curriculum merupakan kurikulum tersembunyi yang memiliki misi khusus diantaranya menanamkan nilai-nilai moral/etika baik yang bersumber dari nilai agama, nilai budaya atau sumber nilai lainnya yang berlaku di masyarakat. Penerapan hidden curriculum di lingkungan pendidikan Islam merupakan solusi untuk mengikis problem lunturnya ahlak/moral yang terjadi pada generasi muda khususnya peserta didik. Keberadaan hidden curriculum bukan hanya bisa diterapkan di lingkungan madrasah, akan tetapi bisa juga diterapkan di lingkungan keluarga dan juga lingkungan masyarakat.

Bentuk-bentuk hidden curriculum di lingkungan pendidikan Islam dapat dilakukan melalui pembiasaan, keteladanan, pengelolaan lingkungan dan pembuatan aturan atau tata tertib yang berlaku di keluarga, tata tertib di madrasah dan tata tertib di lingkungan masyarakat. Oleh sebab itu diperlukan sinergi yang baik antara ketiga lembaga/lingkungan pendidikan tersebut karena satu sama lain saling berpengaruh dan tidak bisa berdiri sendiri dalam mencapai tujuan pendidikan..

\section{DAFTAR PUSTAKA}

Abdullah, Usep Mudani Karim; Azis, Abdul. Efektifitas Strategi Pembelajaran Analisis Nilai Terhadap Pengembangan Karakter Siswa Pada Mata Pelajaran Sejarah Kebudayaan Islam. Jurnal Penelitian Pendidikan Islam, [S.L.], V. 7, N. 1, P. 51-62, June 2019. ISSN 2621-8275. Available At: <http://RisetIaid.Net/Index.Php/JPPI/Article/View/355>. doi: http://doi.org/10.36667/JPPI.V7i1.355. 
Aisah, Iis; Husni, H.; Darisman, Dede. Modernisasi Pendidikan Islam Dalam Perspektif Azyumardi Azra. Jurnal Penelitian Pendidikan Islam, [S.L.], V. 3, N. 2, Aug. 2018. ISSN 2621-8275. Available At: http://RisetIaid.Net/Index.Php/JPPI/Article/View/176

Ali, M. (2010). Guru dalam Proses Belajar Mengajar. Bandung: Sinar Baru Algensindo. Amiruddin, et al. (2017). Manajemen Kurikulum. Medan: Perdana Publishing.

Angrawati, Weni; Al Hamdani, M. Djaswidi. Penggunaan Metode Pembelajaran InsideOutside Circle Untuk Meningkatkan Hasil Belajar Peserta Didik Pada Mata Pelajaran Pendidikan Agama Islam (Penelitian Tindakan Kelas Di Kelas V Sekolah Dasar Negeri 4 Cintanagara, Jatinagara, Kabupaten Ciamis). Jurnal Penelitian Pendidikan Islam, [S.L.], V. 6, N. 2, P. 255-278, Nov. 2018. ISSN 26218275. Available At: <http://Riset-Iaid.Net/Index.Php/JPPI/Article/View/302>. doi: http://doi.org/10.36667/JPPI.V6i2.302.

Ardiagarini, Esti; Daripah, Udung Hari. Nilai-Nilai Pendidikan Islam Dalam Novel "Hafalan Shalat Delisa" Karya Tere Liye. Jurnal Penelitian Pendidikan Islam, [S.L.], V. 5, N. 1, May 2017. ISSN 2621-8275. Available At: http://RisetIaid.Net/Index.Php/JPPI/Article/View/69

Arthur, J. (2003). Education with Character. In Education with Character. https://doi.org/10.4324/9780203220139

Awaliah, Lia Hamdatul; Herlina, N Hani; Munandar, Didih Syakir. Konsep Budaya Membaca Dan Relevansinya Dengan Pendidikan Islam (Studi Analisis Terhadap Buku Spiritual Reading Karya Raghib As-Sirjani). Jurnal Penelitian Pendidikan Islam, [S.L.], V. 4, N. 2, Aug. 2018. ISSN 2621-8275. Available At: http://RisetIaid.Net/Index.Php/JPPI/Article/View/187

Awaliyah, Tuti; Nurzaman, Nurzaman. Konsep Pendidikan Akhlak Menurut Sa'id Hawwa. Jurnal Penelitian Pendidikan Islam, [S.L.], V. 6, N. 1, P. 23-38, May 2018. ISSN 2621-8275. Available At: http://RisetIaid.Net/Index.Php/JPPI/Article/View/152. doi: http://doi.org/10.36667/JPPI.V6i1.152.

Aziz, Irfan Miftahul; Rahmanwangsih, Yuli Altri; Darifah, Udung Hari. Pembelajaran Agama Islam Bagi Anak Penyandang Autisme Di Slb Yksb Cijeungjing Ciamis. Jurnal Penelitian Pendidikan Islam, [S.L.], V. 4, N. 2, Aug. 2018. ISSN 2621-8275. Available At: http://Riset-Iaid.Net/Index.Php/JPPI/Article/View/186

Baehr, J. (2017). The Varieties of Character and Some Implications for Character Education. Journal of Youth and Adolescence, 46(6), 1153-1161. https://doi.org/10.1007/s10964-017-0654-z

Banks, J. A. (2009). Multicultural Education: Characteristics and Goals. In J. A. Banks \& C. A. McGee (Eds.), Multicultural Education: Issues and Perspectives. New York: John Wiley and Sons.

Barrett, B., \& Rata, E. (Eds.). (2014). Knowledge and the Future of the Curriculum. https://doi.org/10.1057/9781137429261 
Burroughs, M. D. (2018). Ethics Across Early Childhood Education. In Ethics Across the Curriculum-Pedagogical Perspectives (pp. 245-260). https://doi.org/10.1007/978-3-319-78939-2_15

Curren, R. (2018). Sustainability Ethics Across the Curriculum. In Ethics Across the Curriculum-Pedagogical Perspectives https://doi.org/10.1007/978-3-319-78939-2_17

(pp.

273-287). 
